\title{
Discovery of Potent and Orally Bioavailable Inverse Agonists of the Retinoic Acid Receptor-Related Orphan Receptor C2
}

Stefan von Berg, ${ }^{\dagger}$ Yafeng Xue, ${ }^{\|}$Mia Collins, ${ }^{\S}$ Antonio Llinas, ${ }^{\ddagger}{ }^{\ddagger}$ Roine I. Olsson, ${ }^{\dagger}$ Torbjörn Halvarsson, ${ }^{\dagger}$ Maria Lindskog, ${ }^{\dagger}$ Jesper Malmberg, ${ }^{\dagger}$ Johan Jirholt, ${ }^{\S}$ Nina Krutrök, ${ }^{\S}$ Marie Ramnegård, ${ }^{\S}$ Marie Brännström, ${ }^{\ddagger}$ Anders Lundqvist, ${ }^{\ddagger}$ Matti Lepistö, ${ }^{\dagger}$ Anna Aagaard, ${ }^{\|}$Jane McPheat, ${ }^{\perp}$ Eva L. Hansson, ${ }^{\perp}$ Rongfeng Chen, ${ }^{\#}$ Yao Xiong, ${ }^{\#}$ Thomas G. Hansson, ${ }^{\dagger}$ and Frank Narjes ${ }^{*}{ }^{\dagger} \odot$

${ }^{\dagger}$ Medicinal Chemistry, ${ }^{\ddagger} \mathrm{DMPK}$, and ${ }^{\S}$ Bioscience, Research and Early Development, Respiratory, Inflammation and Autoimmune, BioPharmaceuticals R\&D, AstraZeneca, Gothenburg, SE-43183 Mölndal, Sweden

"Structure, Biophysics \& FBLG and ${ }^{\perp}$ Mechanistic Biology and Profiling, Discovery Sciences, R\&D, AstraZeneca, Gothenburg, SE-43183 Mölndal, Sweden

"Pharmaron Beijing Co., Ltd., Taihe Road BDA, Beijing 100176, P. R. China

\section{Supporting Information}

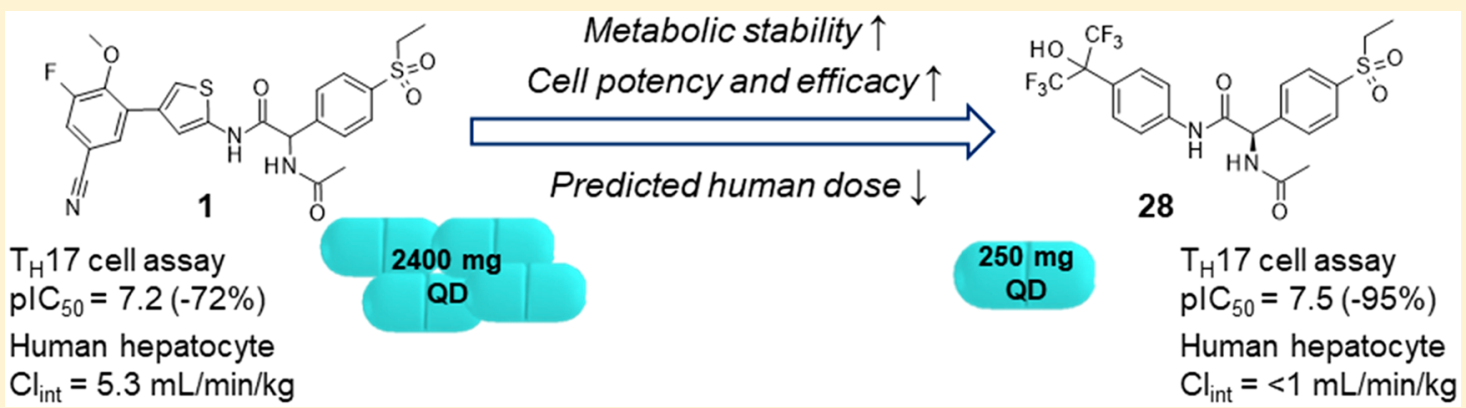

ABSTRACT: The further optimization of a recently disclosed series of inverse agonists of the nuclear receptor RORC2 is described. Investigations into the left-hand side of compound 1, guided by X-ray crystal structures, led to the substitution of the 4-aryl-thiophenyl residue with the hexafluoro-2-phenyl-propan-2-ol moiety. This change resulted in to compound 28, which combined improved drug-like properties with good cell potency and a significantly lower dose, using an early dose to man prediction. Target engagement in vivo was demonstrated in the thymus of mice by a reduction in the number of double positive $\mathrm{T}$ cells after oral dosing.

KEYWORDS: Retinoic acid-related orphan receptor $C$, autoimmune diseases, nuclear receptor, IL-17, dose to man prediction

Tnerse agonists for the retinoic acid-related orphan receptor 1 gamma C2 (RORC2) have been intensely pursued as potential drugs for the treatment of autoimmune disorders. ${ }^{1-7}$ RORC2 is expressed exclusively in the thymus and in cells of the immune system, where it acts as the key transcription factor for the differentiation and development of $\mathrm{T}_{\mathrm{H}} 17$ and other IL-17 producing cells. ${ }^{8}$ Blocking $\mathrm{T}_{\mathrm{H}} 17$ maturation and cytokine expression with an inverse agonist of RORC2 presents an attractive alternative to antibody treatment. ${ }^{9}$ Several antibodies targeting diverse parts of the IL-17 pathway have achieved clinical proof-of-concept in autoimmune diseases such as psoriasis, psoriatic arthritis, and ankylosing spondylitis. $^{10-12}$

Previously we have described a class of inverse agonists of RORC2, exemplified by $\mathbf{1}$ (Table 1$).^{13}$ Compound $\mathbf{1}$ and analogues bind inside the ligand-binding domain (LBD) of RORC2 and modulate receptor function through the ether substituent of the 4-arylthienyl group, which interferes with the cofactor recruitment site on helix 12 (AF2 domain). ${ }^{13,14}$ Large, lipophilic ether groups were necessary to achieve inverse agonism in compounds devoid of the acetamide function shown in 1. Its introduction allowed us to reduce the size of the left-hand side to a methoxy-substituted aryl and to improve physicochemical properties.

Although 1 combined good inhibition of IL-17A production in the cell assay with oral bioavailability in rodents, prediction of the clinically efficacious dose, used within AstraZeneca to evaluate compound quality, revealed that gram amounts of $\mathbf{1}$ would be required for once-daily treatment. ${ }^{15}$

The calculation is based on a conservative approach, where we assumed that $75 \%$ of the dose of 1 would be absorbed from the gut and that the minimum concentration required for effective depletion of IL-17 over $24 \mathrm{~h}$ would be equal to three times the unbound potency in the IL-17 cell assay. Clearance

Received: April 5, 2019

Accepted: May 29, 2019

Published: May 29, 2019 
Table 1. Profile of Compound $1^{a}$

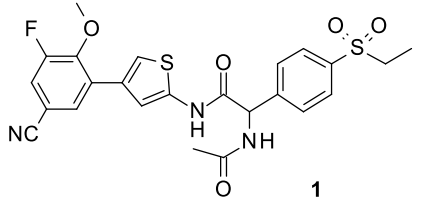

IL-17 cell $\mathrm{pIC}_{50}$ total/free ${ }^{b}$

hPPB (\% free $)^{c}$

$\mathrm{Cl}_{\text {int }} \mathrm{RH} / \mathrm{HH}\left(\mu \mathrm{L} / \mathrm{min} / 10^{6} \text { cells }\right)^{d}$

$7.2 / 7.9$

1.3

$5 / 5.5$

$\begin{array}{ll}\text { Rat } \mathrm{PK}^{e}: \mathrm{Cl}(\mathrm{mL} / \mathrm{min} / \mathrm{kg}), t_{1 / 2}(\mathrm{~h}), \mathrm{Vss}(\mathrm{L} / \mathrm{kg}), \mathrm{F}(\%) & 2.5,2.7,0.34,19 \\ \mathrm{eDtM}(\mathrm{mg}, \mathrm{QD})^{f} & 2400\end{array}$

${ }^{a}$ See Supporting Information for assay details. ${ }^{b}$ Inhibition of IL-17 production from human primary $\mathrm{T}_{\mathrm{H}} 17$ cells; free potency calculated based on protein content in the assay medium. ${ }^{c}$ Binding to human plasma protein determined by equilibrium dialysis. ${ }^{d}$ Rat and human hepatocyte intrinsic clearance. ${ }^{e}$ Pharmacokinetic profile in rat. ${ }^{f}$ Early dose to man prediction.

was predicted from human hepatocytes and the volume of distribution using the Oie-Tozer equation. ${ }^{15}$

Parallel with the SAR leading to $\mathbf{1}$, we had investigated the possibility to simplify the 4-arylthienyl motif of the nonacetamide series, exemplified by 3 (Table 2), to improve its physicochemical properties.

Changing the left-hand side of 3 to a para-substituted biphenyl as in $\mathbf{5}$ was superior with respect to potency to 3 or the meta-substituted analogue 4, but did not improve physicochemical properties. ${ }^{16}$ The X-ray crystal structure of compound 2, a cell active $\left(\mathrm{pIC}_{50}=5.81\right)$ inverse agonist, identified from a high-throughput screening campaign, helped us in addressing this issue. ${ }^{17}$ Soaking 2 in the agonist form of the RORC2 LBD returned the $(R)$-enantiomer as the bound species (Figure 1). An overlay with 1 showed that both compounds established the same hydrogen bond interactions with their amide moieties to Glu379 and Phe377, respectively. The isopropyl group on the phenyl substituent of $\mathbf{2}$ partially filled the volume occupied by the methoxy residue of the 4-aryl group on the thiophene, indicating that the 4-chlorophenyl group in 5 could be replaced with a simpler residue.

Replacement of the 4-chlorophenyl group in 5 with isopropyl resulted in inactive compound 6. Speculating that either a polar group, mimicking the methoxy group in 1 , or enhanced steric bulk could lead to active compounds led us to the preparation of analogues containing a diverse set of parasubstituents. While introduction of an isopropyl cyano (7) or methoxy (8) substituent improved activity in the FRET and cell assay and also physicochemical properties, the bistrifluoromethyl-isopropanol moiety in $\mathbf{9}$ proved to be the optimal choice, leading to efficacious inhibition of IL-17A production. The introduction of the two trifluoromethyl groups led to a relatively high $\log \mathrm{D}$, but overall solubility with respect to 3 was improved, due to the slight acidic nature of the hydroxy group (measured $\mathrm{p} K_{\mathrm{a}}=8.85$ ). Methoxy and nitrile analogues 10 and $\mathbf{1 1}$ exhibited marginally improved potency in the cell assay but were 8 -fold less soluble. Elimination of the hydroxy group from 9 reduced activity by about 10-fold (12), whereas elimination of one trifluoromethyl group resulted in inactive compound $\mathbf{1 3}$.

The hexafluoro-2-phenyl-propan-2-ol moiety is part of T0901317, a known agonist of the liver X receptor, from which diverse groups developed structurally diverse inverse agonists of RORC2. ${ }^{18-20}$ Compound 9 did not display any
Table 2. Modification of the LHS $^{a}$<smiles>[R]NC(=O)Cc1ccc(S(=O)(=O)CC)cc1</smiles>

\begin{tabular}{|c|c|c|c|c|c|}
\hline \multirow{2}{*}{ Cmpd } & \multirow{2}{*}{$\mathrm{R}$} & \multicolumn{2}{|c|}{$\mathrm{pIC}_{50}(\%$ eff. $)$} & \multirow{2}{*}{$\log \mathrm{D}^{d}$} & \multirow{2}{*}{$\begin{array}{l}\text { Sol. } \\
(\mu \mathrm{M})^{e}\end{array}$} \\
\hline & & FRET $^{b}$ & IL-17 ${ }^{c}$ & & \\
\hline 3 & $\mathrm{Cl}$ & $\begin{array}{l}6.8 \\
(-96)\end{array}$ & ND & $>4.1$ & 0.4 \\
\hline 4 & & $\begin{array}{l}6.8 \\
(-98)\end{array}$ & $\begin{array}{l}5.8 \\
(-46)\end{array}$ & $>4$ & 1.5 \\
\hline 5 & & $\begin{array}{l}7.2 \\
(-85)\end{array}$ & $\begin{array}{l}6.5 \\
(-44)\end{array}$ & $>4$ & 0.6 \\
\hline 6 & & $<5$ & N.D. & 3.5 & 11 \\
\hline 7 & & $\begin{array}{l}6.5 \\
(-52)\end{array}$ & $\begin{array}{l}5.7 \\
(-63)\end{array}$ & 2.5 & 42 \\
\hline 8 & & $\begin{array}{l}6.9 \\
(-63)\end{array}$ & $\begin{array}{l}6.0 \\
(-36)\end{array}$ & 2.5 & 181 \\
\hline 9 & & $\begin{array}{l}7.6 \\
(-92)\end{array}$ & $\begin{array}{l}7.0 \\
(-89)\end{array}$ & 3.6 & 53 \\
\hline 10 & & $\begin{array}{l}7.5 \\
(-46)\end{array}$ & $\begin{array}{l}7.1 \\
(-66)\end{array}$ & 4 & 7 \\
\hline 11 & & $\begin{array}{l}7.0 \\
(-62)\end{array}$ & $\begin{array}{l}7.3 \\
(-84)\end{array}$ & 4.3 & 7 \\
\hline 12 & & $\begin{array}{l}6.9 \\
(-56)\end{array}$ & $\begin{array}{l}6.2 \\
(-61)\end{array}$ & 3.9 & 67 \\
\hline 13 & & $<5$ & N.D. & 2.1 & 206 \\
\hline
\end{tabular}

${ }^{a} \mathrm{pIC}_{50}$ data are the mean of at least two independent measurements unless otherwise stated; see Table S1. ${ }^{b}$ Recruitment of SRC1-derived coactivator peptide; $\mathrm{pIC}_{50} \mathrm{SEM}$ is $<0.37$. ${ }^{c}$ Inhibition of IL-17A production from human primary $\mathrm{T}_{\mathrm{H}} 17$ cells; $\%$ efficacy (\% eff.) relative to DMSO control; $\mathrm{pIC}_{50} \mathrm{SEM}$ is $<0.31$. ${ }^{d}$ Distribution coefficient between 1-octanol and aqueous phosphate buffer at $\mathrm{pH}$ 7.4. ${ }^{e}$ Determined from DMSO stock solutions in aqueous buffer at $\mathrm{pH}$ 7.4. ND, not determined.

agonistic activity against $\operatorname{LXR} \alpha$ and $\beta$ up to a concentration of $10 \mu \mathrm{M}$ in a reporter gene assay. It was also found to be inactive against other ROR isoforms and related retinoic acid receptors $\alpha, \beta$, and $\gamma$.

Combining the hexafluoro-2-phenyl-propan-2-ol moiety with the phenylglycine residue found in $\mathbf{1}$ resulted in 14, which combined enhanced cell potency and full efficacy in suppressing IL-17 production with superior metabolic stability 


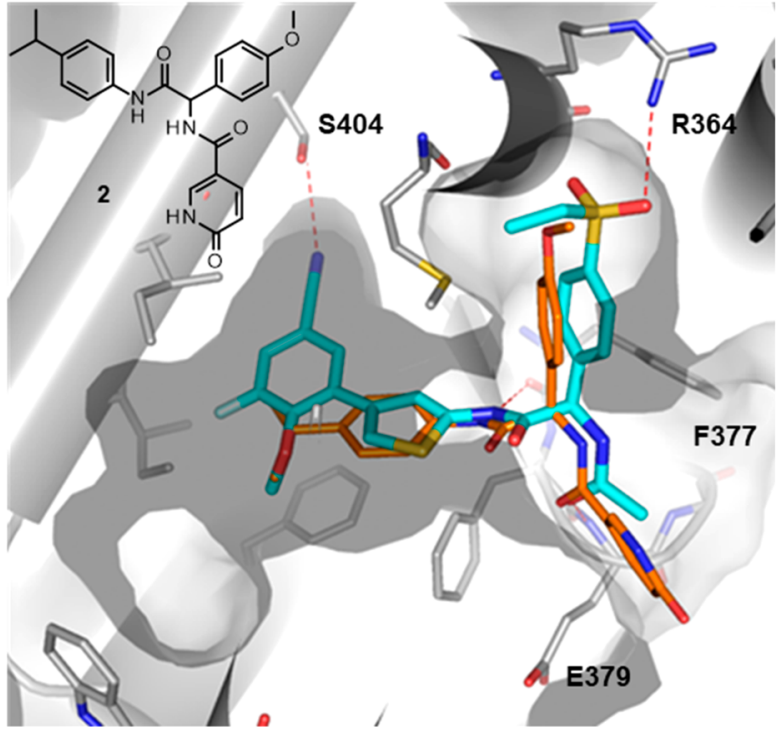

Figure 1. Overlay of 1 (1.84 Å, PDB: 6ESN, carbons in cyan) and HTS hit 2 (2.1 $\AA$, PDB: 6R7A carbons in orange) in the RORC2 LBD.

and solubility compared to $\mathbf{1}$ (Table 3 ). The unsubstituted amine $\mathbf{1 5}$ is about 6-fold less potent in the cell assay. This potency difference is not reflected in the FRET assay, which is also observed for other compounds in Table 3. The result is due to the assay conditions, placing a limit on the highest $\mathrm{pIC}_{50}$ that can be determined at around 7.5. Compounds 14 and 15 displayed agonistic activity on RORA in the lower micromolar range, as determined by a cofactor recruitment assay, but were inactive as inverse agonists, as all compounds in Table 3. Compound $\mathbf{1 4}$ was also inactive against RORB or other nuclear receptors such as retinoic acid receptors $\alpha, \beta$, and $\gamma$.

We briefly investigated the SAR around the acetamide residue to see if we could further improve cell potency, without compromising on the physicochemical properties. Carbamate 16 was comparable in potency to amide 14 , whereas urea 17 and sulphonamide 18 were inferior. Increasing the size of the amide substituent to isobutyl, as in 19, improved cell potency by about 3-fold, but at the expense of metabolic stability and solubility. Introduction of a hydroxy group into the isobutyl residue as in $\mathbf{2 0}$ improved overall properties, but not cell potency.

Aromatic residues were tolerated, and benzoate $\mathbf{2 1}$ or phenylpropionate 23 showed cell potencies similar to 14 . Phenylacetamide 22 was an exception, being 10-fold more active in the cell assay. As observed for 19, the higher $\log \mathrm{D}$ resulted in higher turnover in rat hepatocytes and a loss in solubility. Incorporation of nitrogen atoms as in compounds 24-27 caused generally a loss in cell potency with respect to 22. This was less pronounced for the 2-pyridyl and the 3pyridazinyl analogues 24 and 26, but despite their lower $\log \mathrm{D}$, turnover in rat hepatocytes and solubility did not improve. Interestingly, the carbamate linkage in $\mathbf{1 6}$ and the bulkier amide residues in $\mathbf{1 9}$ or $\mathbf{2 0}$ as well as introduction of nitrogen atoms into 22 abolished activity on RORA.

The X-ray cocrystal structures of $\mathbf{1 4}$ and 22, obtained by soaking the compounds into the apo crystals of RORC2-LBD in the presence of bound SRC2 peptide, returned their

Table 3. Impact of the Amine Substituent on Activity and Metabolic Stability ${ }^{a}$<smiles>[R]NC(C(=O)Nc1ccc(C(F)(F)F)cc1)c1ccc(S(=O)(=O)CC)cc1</smiles>

\begin{tabular}{|c|c|c|c|c|c|c|c|}
\hline Cmpd & $\mathrm{R}$ & FRET $\mathrm{pIC}_{50}(\% \text { eff. })^{b}$ & IL-17 Cell pIC 50 (\% eff. $)^{c}$ & $\log \mathrm{D}^{d}$ & Sol. $(\mu \mathrm{M})^{e}$ & RH Clint ${ }^{f}$ & RORA $\mathrm{pIC}_{50}{ }^{8}$ \\
\hline 1 & & $7.2(-72)$ & $7.2(-72)$ & 3.3 & 205 & 5 & 4.5 \\
\hline 14 & $\mathrm{C}(\mathrm{O}) \mathrm{Me}$ & $7.4(-99)$ & $7.3(-91)$ & 3.1 & 621 & $<1$ & 5.6 \\
\hline 15 & $\mathrm{H}$ & $7.4(-94)$ & $6.6(-91)$ & 2.8 & 150 & 2.5 & 5.8 \\
\hline 16 & $\mathrm{C}(\mathrm{O}) \mathrm{OMe}$ & $7.3(-97)$ & $7.2(-88)$ & 3.6 & 150 & 2.5 & $<4.5$ \\
\hline 17 & $\mathrm{C}(\mathrm{O}) \mathrm{NHMe}$ & $7.4(-98)$ & $6.6(-89)$ & 3.2 & 155 & 5.4 & ND \\
\hline 18 & $\mathrm{SO}_{2} \mathrm{Me}$ & $7.1(-97)$ & $6.9(-91)$ & 2.7 & 447 & $<1$ & ND \\
\hline 19 & $\mathrm{C}(\mathrm{O}) \mathrm{CH}_{2}-\mathrm{iPr}$ & $7.1(-94)$ & $7.8(-96)$ & $>4$ & 28 & 9 & $<4.5$ \\
\hline 20 & $\mathrm{C}(\mathrm{O}) \mathrm{CH}_{2} \mathrm{C}(\mathrm{OH}) \mathrm{Me}_{2}$ & $7.1(-97)$ & $7.3(-91)$ & 3.3 & 241 & 1.3 & $<4.5$ \\
\hline 21 & $\mathrm{C}(\mathrm{O}) \mathrm{Ph}$ & $7.0(-97)$ & $7.4(-95)$ & $>4$ & 1.4 & 3.6 & ND \\
\hline 22 & $\mathrm{C}(\mathrm{O}) \mathrm{CH}_{2} \mathrm{Ph}$ & $7.3(-92)$ & $8.5(-95)$ & 4 & 11 & 23 & 5.7 \\
\hline 23 & $\mathrm{C}(\mathrm{O})\left(\mathrm{CH}_{2}\right)_{2} \mathrm{Ph}$ & $7.1(-100)$ & $7.4(-97)$ & $>4$ & 0.03 & 54 & ND \\
\hline 24 & $\mathrm{C}(\mathrm{O}) \mathrm{CH}_{2}-2$-pyridyl & $7.3(-97)$ & $7.9(-97)$ & 3.3 & 2.7 & 17 & $<4.5$ \\
\hline 25 & $\mathrm{C}(\mathrm{O}) \mathrm{CH}_{2}-2$-pyridazyl & $7.2(-95)$ & $7.0(-89)$ & 2.5 & 110 & 4.3 & ND \\
\hline 26 & $\mathrm{C}(\mathrm{O}) \mathrm{CH}_{2}-3$-pyridazyl & $7.2(-95)$ & $7.6(-89)$ & 2.9 & 3.4 & 24 & $<4.5$ \\
\hline 27 & $\mathrm{C}(\mathrm{O}) \mathrm{CH}_{2}-3$-pyrimidyl & $7.3(-97)$ & $7.4(-90)$ & 2.8 & 177 & 6 & ND \\
\hline 28 & $\mathrm{C}(\mathrm{O}) \mathrm{Me}(R)$ & $7.5(-95)$ & $7.5(-95)$ & 3.0 & 381 & $<1$ & 6.3 \\
\hline 29 & $\mathrm{C}(\mathrm{O}) \mathrm{Me}(\mathrm{S})$ & $5.6(-98)$ & $7.1(-91)$ & 3.1 & 326 & $<1$ & $<4.5$ \\
\hline
\end{tabular}

${ }^{a} \mathrm{pIC}_{50}$ data are the mean of at least two independent measurements unless otherwise stated; see Table S1. ${ }^{b}$ Recruitment of SRC1-derived coactivator peptide; $\mathrm{pIC}_{50} \mathrm{SEM}$ is $<0.37$. ${ }^{c}$ Inhibition of IL-17A production from human primary $\mathrm{T}_{\mathrm{H}} 17$ cells; \% efficacy (\% eff.) relative to DMSO control; $\mathrm{pIC}_{50}$ SEM is $<0.31$. ${ }^{d}$ Distribution coefficient between 1-octanol and aqueous phosphate buffer at $\mathrm{pH}$ 7.4. ${ }^{e}$ Determined from DMSO stock solutions in aqueous buffer at $\mathrm{pH}$ 7.4. ND, not determined. ${ }^{f}$ Rat hepatocyte intrinsic clearance $\left(\mu \mathrm{L} / \mathrm{min}^{1} / 10^{6}\right.$ cells). ${ }^{g}$ Time-resolved (TR)-FRET assay in agonist mode using a peptide derived from PGC1 $\alpha$ 130-154; ND, not determined. 
respective $R$-isomers as the bound species (Figure 2). We have shown previously that the ligand interactions in such agonist

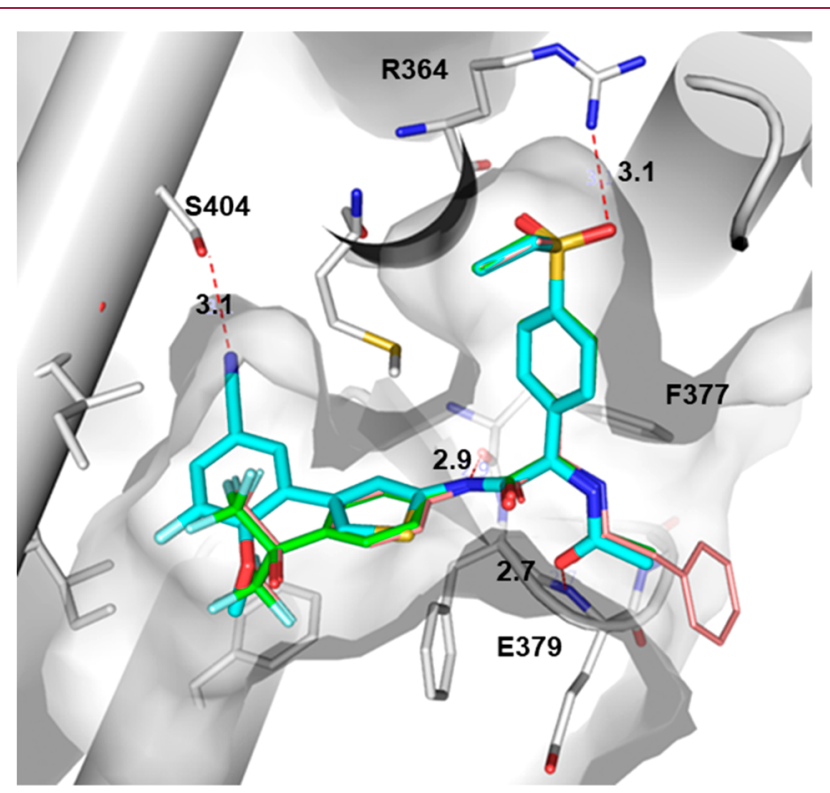

Figure 2. Overlay of $\mathbf{1}$ (1.84 A, PDB: 6ESN, carbons in cyan), 14 (1.8 Å, PDB: 6R7J, carbons in green), and 22 (1.5 Å, PDB: 6R7K, carbons in pink) with key interactions to the RORC2 LBD.

conformation would render the same binding mode as in the cocrystals without the coactivator peptide. ${ }^{21}$ Their right-hand side moieties overlapped well and established the same hydrogen bonds inside the pocket and outside the LBD, namely, to Arg364, Phe377, and Glu379. The enhanced cell activity of 22 can be explained by the interaction of the phenylacetamide with a hydrophobic stretch outside the LBD.

On the left-hand side, the bis-trifluoromethyl groups occupied a space in front of the 4-aryl residue of 1 , extending above and below the plane of the phenyl residues, which overlap with the thiophene of $\mathbf{1}$. The interaction with Ser404 is lost, and this might be the reason for the activity observed on RORA. The Phe-C $\left(\mathrm{CF}_{3}\right)_{2} \mathrm{OH}$ moiety is located in a hydrophobic environment, at about 7-8 $\AA$ away from the cofactor recruitment site, but not exactly in the same place as in previously reported inverse agonists (see Figure S3). ${ }^{20}$ Its local conformation, with the hydroxy group pointing towards helix 12 , suggests that it modulates receptor function through indirect interactions with this region (Figure S1). Although a more thorough analysis is needed, an overlay of the LBD's of RORA and RORC suggested that the observed selectivity against RORA with either carbamate, branched, or polar acetamide residues could be due to a narrower and more hydrophobic channel in RORA (Figure S2).

Compound 14 was separated into its enantiomers, and the more active enantiomer $\mathbf{2 8}$ was assigned the $(R)$-configuration, based on the X-ray structure. The $(S)$-isomer 29 was about 100 -fold less active in the FRET assay but showed higher than expected activity in the cell assay. We believe this to be due to racemization of the compounds in the medium of the cell assay, as we have previously demonstrated for a close derivative of $\mathbf{1}{ }^{13}$ Isomer $\mathbf{2 8}$ was also more active on RORA. Further profiling of 22,28 , and 29 revealed that they showed good crossover to mouse, as evaluated by radioligand binding assays (Table 4). Compound 22 showed moderate stability in human
Table 4. Profile of Selected Compounds

\begin{tabular}{|c|c|c|c|}
\hline Cmpd & 22 & 28 & 29 \\
\hline hRORC SPA $^{a}$ & 7.4 & 7.3 & 6.1 \\
\hline mRORC SPA $^{a}$ & 7.6 & 6.9 & 5.4 \\
\hline hPРB $(\% \text { free })^{b}$ & 0.72 & 12 & 10 \\
\hline IL-17 cell pIC free $^{c}$ & 9.4 & 7.6 & 7.3 \\
\hline $\mathrm{Cl}_{\text {int }} \mathrm{HH}^{d}\left(\mu \mathrm{L} / \mathrm{min} / 10^{-6}\right.$ cells $)$ & 4.3 & $<1$ & $<1$ \\
\hline $\operatorname{eDTM}(\mathrm{mg}, \mathrm{QD})^{e}$ & 900 & 250 & \\
\hline \multicolumn{4}{|l|}{ Rat $\mathrm{PK}^{f}$} \\
\hline $\mathrm{Cl}(\mathrm{mL} / \mathrm{min} / \mathrm{kg}), t_{1 / 2}(\mathrm{~h})$ & $53,4.9$ & $18.2,3.7$ & ND \\
\hline Vss $(\mathrm{L} / \mathrm{kg}), \mathrm{F}(\%)$ & $10.2,5$ & $2.2,20$ & ND \\
\hline \multicolumn{4}{|l|}{ Mouse $\mathrm{PK}^{f}$} \\
\hline $\mathrm{Cl}(\mathrm{mL} / \mathrm{min} / \mathrm{kg}), t_{1 / 2}(\mathrm{~h})$ & ND & $14,3.3$ & $16,2.9$ \\
\hline Vss(L/kg), F (\%) & ND & $2.4,27$ & $2.7,28$ \\
\hline
\end{tabular}

${ }^{a}$ Scintillation proximity competition binding assay (SPA). ${ }^{b}$ Binding to human plasma protein determined by equilibrium dialysis. ${ }^{c}$ Inhibition of IL-17A production from human primary $\mathrm{T}_{\mathrm{H}} 17$ cells; $\%$ efficacy (\% eff.) relative to DMSO control; $\mathrm{pIC}_{50} \mathrm{SEM}$ is $<0.31{ }^{d}$ Distribution coefficient between 1-octanol and aqueous phosphate buffer at $\mathrm{pH}$ 7.4. ${ }^{e}$ Determined from DMSO stock solutions in aqueous buffer at $\mathrm{pH}$ 7.4. ${ }^{f}$ Pharmacokinetic profile in rat and mouse. For experimental conditions, see Supporting Information. ND, not determined.

hepatocytes, similar to $\mathbf{1}$, whereas $\mathbf{2 8}$ and $\mathbf{2 9}$ were stable. Single dose rat PK of $\mathbf{2 2}$ was characterized by high plasma clearance and low bioavailability, in line with clearance data from rat hepatocytes. The rat PK of $\mathbf{2 8}$ was comparable to $\mathbf{1}$, revealing moderate plasma clearance and reasonable oral bioavailability. Compared to 1, permeability and efflux of 28, determined in Caco2-cells, were not significantly improved $\left(0.3 / 0.49 \times 10^{-6}\right.$ $\mathrm{cm} / \mathrm{s}$ and $50 / 17$, respectively). We calculated the early dose to man as described above for compound 1. A clear improvement for compound 28, with respect to $\mathbf{1}$ and $\mathbf{2 2}$, is evident, due mainly to its enhanced metabolic stability, resulting in a significant reduction in predicted human clearance.

We established an in vivo model that allowed us to evaluate the effect of RORC2 inhibition in the thymus of mice. Maturation and survival of double positive $\left(\mathrm{CD} 4^{+} \mathrm{CD} 8^{+}\right) \mathrm{T}$ cells in the thymus depends on RORC2. It has been shown that germline knockout of the receptor in the mouse leads to a reduction of the number of double positive cells. ${ }^{22}$

The mouse PK for $\mathbf{2 8}$ and $\mathbf{2 9}$ displayed almost identical profiles and was similar to the rat PK of $\mathbf{2 8}$ (Table 4). Only a small extent of racemization $(<5 \%)$ was observed in plasma at $24 \mathrm{~h}$.

Compounds were then dosed orally at $50 \mathrm{mg} / \mathrm{kg}$ twice a day for 2 days to six-week-old C57BL/ 6 female mice. Afterwards, a single cell suspension from each thymus was prepared and cells stained for flow cytometric analysis to assess the absolute numbers of double positive $\left(\mathrm{CD} 4^{+} \mathrm{CD}^{+}\right)$thymocytes (Figure 3). Compound 28 significantly reduced their number by about $40 \%(p=0.008)$, whereas enantiomer 29 had no effect. Exposure levels for compounds $\mathbf{2 8}$ and 29 at 48 h were similar, with $240 \pm 150$ and $145 \pm 45 \mathrm{nM}$, respectively. Free terminal plasma exposure of compound 28 was calculated to be $28 \mathrm{nM}$, which corresponds to the unbound $\mathrm{IC}_{50}$ value in the cell assay. The lack of effect for $\mathbf{2 9}$ is in line with its weak binding activity on mouse RORC.

In summary we have further improved our series of phenylglycine based RORC2 inverse agonist. Investigations into the left-hand side of compound $\mathbf{1}$, inspired by the X-ray cocrystal structure of 2 , led to the substitution of the arylthiophenyl residue with a hexafluoro-2-phenyl-propan-2-ol 


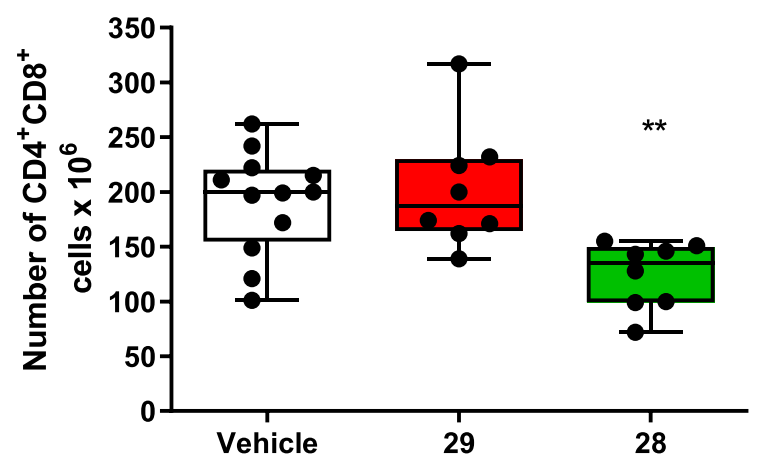

Figure 3. Effect of compounds 28 and 29 on the number of $\mathrm{CD} 4^{+} \mathrm{CD} 8^{+} \mathrm{T}$ cells in the thymus of mice.

moiety, reducing the number of aromatic rings from three to two and led to compound 28, which showed good cellular potency with full suppression of IL-17 production. It also resulted in an overall improvement in drug-like properties. Using early dose to man prediction as a benchmark, compound 28 requires 6-fold lower dosing compared to 1 . Oral dosing to mice showed engagement of RORC2 in vivo, as demonstrated by a reduction in the number of double positive $\mathrm{T}$ cells in the thymus.

For the synthesis of phenylglycine derivatives, amine $\mathbf{1 5}$ was prepared by amide coupling of 30 to acid $32^{13}$ and subsequent deprotection of the Boc group. Reaction with the appropriate acylating reagent furnished the desired products. Acetate 14 was further separated into the enantiomers $\mathbf{2 8}$ and $\mathbf{2 9}$ (Scheme $1)$.

Scheme 1. Synthesis of Analogues 14, 16, 22, 28, and $29^{a}$

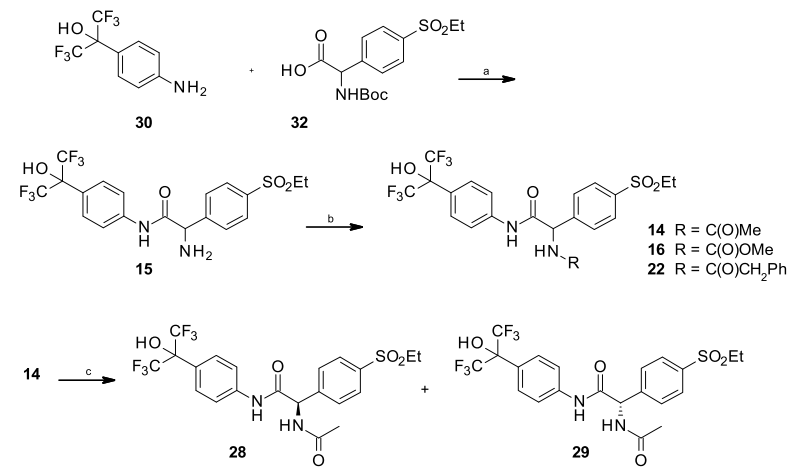

${ }^{a}$ Reagents and conditions: (a) HATU, $i-\mathrm{PrNEt}_{2}, \mathrm{CH}_{2} \mathrm{Cl}_{2} 85 \%$; $\mathrm{HCl}$, 1,4-dioxane, RT or TFA, $\mathrm{CH}_{2} \mathrm{Cl}_{2}$, quant.; (b) for 14: $\mathrm{MeCN}, \mathrm{AcCl}$, $\mathrm{NEt}_{3}, 89 \%$; for 16: $\mathrm{MeCN}, \mathrm{MeOCOCl}, i-\mathrm{PrNEt}_{2}, 64 \%$; for 22: $\mathrm{PhCH}_{2} \mathrm{CO}_{2} \mathrm{H}, \mathrm{T}_{3} \mathrm{P}, \mathrm{TEA}, \mathrm{CH}_{2} \mathrm{Cl}_{2}, \mathrm{RT}, 85 \%$; (c) SFC, $30 \% i-\mathrm{PrOH}$ in $\mathrm{CO}_{2}, 120$ bar: 28 (41\%), 29 (41\%).

\section{ASSOCIATED CONTENT}

\section{S Supporting Information}

The Supporting Information is available free of charge on the ACS Publications website at DOI: 10.1021/acsmedchemlett.9b00158.

Experimental procedures and characterization data for intermediates and all final compounds, conditions for biological assays, and crystal structure information (PDF)

\section{Accession Codes}

PDB accession codes 6R7A (2), 6R7K (22), and 6R7J (14/ 28). The authors will release the atomic coordinates and experimental data upon publication.

\section{AUTHOR INFORMATION}

\section{Corresponding Author}

*E-mail: Frank.Narjes@astrazeneca.com. Tel: +46 706468373. ORCID

Antonio Llinas: 0000-0003-4620-9363

Frank Narjes: 0000-0002-3104-7771

\section{Author Contributions}

F.N., A.L., J.J., J.M., and T.G.H. conceived and designed the experiments; F.N., S.v.B., R.I.O., T.H., M.L., J.M., M.Lep., R.C., and Y.Xi. designed and/or synthesized compounds; A.A. and Y.X. provided X-ray structure data; A.L., M.C., J.J., N.K., M.R., M.B., and A.L. designed and/or performed and analyzed the in vivo studies; J.M. and E.L.H. provided in vitro assay data;. F.N. wrote the manuscript with contributions from Y.X., A.L., J.M., S.v.B., and M.C.

\section{Notes}

All animal experiments were approved by the Pharmaron's Institutional Animal Care and Use Committee (IACUC) in Pharmaron and by the Gothenburg Ethics Committee for Experimental Animals Sweden; both conform to Directive 2010/63/EU. Animal handling conformed to standards established by the Council of Europe ETS123 AppA, NIH guidelines on animal welfare, Chinese legislation and Pharmaron's IACUC policies and procedures, the Helsinki Convention for the Use and Care of Animals, Swedish legislation, and AstraZeneca Global Internal Standards. The authors declare no competing financial interest.

\section{ACKNOWLEDGMENTS}

The authors would like to thank the analytical group, the SSL group, and Anna Malmberg for the purification and characterization of compounds. We acknowledge Catarina Johansson for SPR measurements of compound 2, Agnes Leffler and Elisabeth Bäck for providing the cell data, and the IMED RIA in vivo team for support of the mouse study.

\section{ABBREVIATIONS}

FRET, fluorescence resonance energy transfer; HATU, O-(7azabenzotriazol-1-yl)- $N, N, N^{\prime}, N^{\prime}$-tetramethyluronium-hexafluor-phosphate; LBD, ligand binding domain; PK, pharmacokinetics; ROR, retinoic acid receptor-related orphan receptor; SAR, structure-activity relationship; SPA, scintillation proximity assay; SRC, steroid receptor coactivator

\section{REFERENCES}

(1) Cyr, P.; Bronner, S. M.; Crawford, J. J. Recent progress on nuclear receptor ROR $\gamma$ modulators. Bioorg. Med. Chem. Lett. 2016, 26, 4387-4393.

(2) Pandya, V. B.; Kumar, S.; Sachchidanand; Sharma, R.; Desai, R. C. Combating Autoimmune Diseases With Retinoic Acid ReceptorRelated Orphan Receptor- $\gamma$ (ROR $\gamma$ or RORc) Inhibitors: Hits and Misses. J. Med. Chem. 2018, 61, 10976-10995.

(3) Schnute, M. E.; Wennerstål, M.; Alley, J.; Bengtsson, M.; Blinn, J. R.; Bolten, C. W.; Braden, T.; Bonn, T.; Carlsson, B.; Caspers, N.; Chen, M.; Choi, C.; Collis, L. P.; Crouse, K.; Färnegårdh, M.; Fennell, K. F.; Fish, S.; Flick, A. C.; Goos-Nilsson, A.; Gullberg, H.; Harris, P. K.; Heasley, S. E.; Hegen, M.; Hromockyj, A. E.; Hu, X.; Husman, B.; Janosik, T.; Jones, P.; Kaila, N.; Kallin, E.; Kauppi, B.; Kiefer, J. R.; 
Knafels, J.; Koehler, K.; Kruger, L.; Kurumbail, R. G.; Kyne, R. E.; Li, W.; Löfstedt, J.; Long, S. A.; Menard, C. A.; Mente, S.; Messing, D.; Meyers, M. J.; Napierata, L.; Nöteberg, D.; Nuhant, P.; Pelc, M. J.; Prinsen, M. J.; Rhönnstad, P.; Backström-Rydin, E.; Sandberg, J.; Sandström, M.; Shah, F.; Sjöberg, M.; Sundell, A.; Taylor, A. P.; Thorarensen, A.; Trujillo, J. I.; Trzupek, J. D.; Unwalla, R.; Vajdos, F. F.; Weinberg, R. A.; Wood, D. C.; Xing, L.; Zamaratski, E.; Zapf, C. W.; Zhao, Y.; Wilhelmsson, A.; Berstein, G. Discovery of 3-Cyano-N(3-(1-isobutyrylpiperidin-4-yl)-1-methyl-4-(trifluoromethyl)-1Hpyrrolo[2,3-b]pyridin-5-yl)benzamide: A Potent, Selective, and Orally Bioavailable Retinoic Acid Receptor-Related Orphan Receptor C2 Inverse Agonist. J. Med. Chem. 2018, 61, 10415-10439.

(4) Sasaki, Y.; Odan, M.; Yamamoto, S.; Kida, S.; Ueyama, A.; Shimizu, M.; Haruna, T.; Watanabe, A.; Okuno, T. Discovery of a potent orally bioavailable retinoic acid receptor-related orphan receptor-gamma-t (ROR $\gamma$ t) inhibitor, S18-000003. Bioorg. Med. Chem. Lett. 2018, 28, 3549-3553.

(5) Ouvry, G.; Bihl, F.; Bouix-Peter, C.; Christin, O.; Defoin-Platel, C.; Deret, S.; Feret, C.; Froude, D.; Hacini-Rachinel, F.; Harris, C. S.; Hervouet, C.; Lafitte, G.; Luzy, A.-P.; Musicki, B.; Orfila, D.; Parnet, V.; Pascau, C.; Pascau, J.; Pierre, R.; Raffin, C.; Rossio, P.; Spiesse, D.; Taquet, N.; Thoreau, E.; Vatinel, R.; Vial, E.; Hennequin, L. F. Sulfoximines as potent ROR $\gamma$ inverse agonists. Bioorg. Med. Chem. Lett. 2018, 28, 1269-1273.

(6) Kono, M.; Ochida, A.; Oda, T.; Imada, T.; Banno, Y.; Taya, N.; Masada, S.; Kawamoto, T.; Yonemori, K.; Nara, Y.; Fukase, Y.; Yukawa, T.; Tokuhara, H.; Skene, R.; Sang, B. C.; Hoffman, I. D.; Snell, G. P.; Uga, K.; Shibata, A.; Igaki, K.; Nakamura, Y.; Nakagawa, H.; Tsuchimori, N.; Yamasaki, M.; Shirai, J.; Yamamoto, S. Discovery of [ cis-3-(\{(5 R)-5-[(7-Fluoro-1,1-dimethyl-2,3-dihydro-1 H-inden5-yl)carbamoyl]-2-methoxy-7,8-dihydro-1,6-naphthyridin-6(5 H)-yl\}carbonyl)cyclobutyl]acetic Acid (TAK-828F) as a Potent, Selective, and Orally Available Novel Retinoic Acid Receptor-Related Orphan Receptor gammat Inverse Agonist. J. Med. Chem. 2018, 61, 29732988.

(7) Kummer, D. A.; Cummings, M. D.; Abad, M.; Barbay, J.; Castro, G.; Wolin, R.; Kreutter, K. D.; Maharoof, U.; Milligan, C.; Nishimura, R.; Pierce, J.; Schalk-Hihi, C.; Spurlino, J.; Urbanski, M.; Venkatesan, H.; Wang, A.; Woods, C.; Xue, X.; Edwards, J. P.; Fourie, A. M.; Leonard, K. Identification and structure activity relationships of quinoline tertiary alcohol modulators of ROR $\gamma \mathrm{t}$. Bioorg. Med. Chem. Lett. 2017, 27, 2047-2057.

(8) Cook, D. N.; Kang, H. S.; Jetten, A. M. Retinoic Acid-Related Orphan Receptors (RORs): Regulatory Functions in Immunity, Development, Circadian Rhythm, and Metabolism. Nucl. Receptor Res. 2015, 2, 101185.

(9) Bassolas-Molina, H.; Raymond, E.; Labadia, M.; Wahle, J.; Ferrer-Picón, E.; Panzenbeck, M.; Zheng, J.; Harcken, C.; Hughes, R.; Turner, M.; Smith, D.; Calderón-Gómez, E.; Esteller, M.; Carrasco, A.; Esteve, M.; Dotti, I.; Corraliza, A. M.; Masamunt, M. C.; Arajol, C.; Guardiola, J.; Ricart, E.; Nabozny, G.; Salas, A. An ROR $\gamma$ t Oral Inhibitor Modulates IL-17 Responses in Peripheral Blood and Intestinal Mucosa of Crohn's Disease Patients. Front. Immunol. 2018, 9, 2307.

(10) Mease, P. J. Inhibition of interleukin-17, interleukin-23 and the TH17 cell pathway in the treatment of psoriatic arthritis and psoriasis. Curr. Opin. Rheumatol. 2015, 27, 127-133.

(11) Boutet, M.-A.; Nerviani, A.; Gallo Afflitto, G.; Pitzalis, C. Role of the IL-23/IL-17 Axis in Psoriasis and Psoriatic Arthritis: The Clinical Importance of Its Divergence in Skin and Joints. Int. J. Mol. Sci. 2018, 19, 530.

(12) Baeten, D.; Sieper, J.; Braun, J.; Baraliakos, X.; Dougados, M.; Emery, P.; Deodhar, A.; Porter, B.; Martin, R.; Andersson, M.; Mpofu, S.; Richards, H. B. Secukinumab, an Interleukin-17A Inhibitor, in Ankylosing Spondylitis. N. Engl. J. Med. 2015, 373, 2534-2548.

(13) Narjes, F.; Xue, Y.; von Berg, S.; Malmberg, J.; Llinas, A.; Olsson, R. I.; Jirholt, J.; Grindebacke, H.; Leffler, A.; Hossain, N.; Lepistö, M.; Thunberg, L.; Leek, H.; Aagaard, A.; McPheat, J.; Hansson, E. L.; Bäck, E.; Tångefjord, S.; Chen, R.; Xiong, Y.;
Hongbin, G.; Hansson, T. G. Potent and Orally Bioavailable Inverse Agonists of ROR $\gamma$ t Resulting from Structure-Based Design. J. Med. Chem. 2018, 61, 7796-7813.

(14) Kallen, J.; Izaac, A.; Be, C.; Arista, L.; Orain, D.; Kaupmann, K.; Guntermann, C.; Hoegenauer, K.; Hintermann, S. Structural States of ROR $\gamma \mathrm{t}$ : X-ray Elucidation of Molecular Mechanisms and Binding Interactions for Natural and Synthetic Compounds. ChemMedChem 2017, 12, 1014-1021.

(15) Page, K. M. Validation of Early Human Dose Prediction: A Key Metric for Compound Progression in Drug Discovery. Mol. Pharmaceutics 2016, 13, 609-620.

(16) Wang, Y.; Cai, W.; Cheng, Y.; Yang, T.; Liu, Q.; Zhang, G.; Meng, Q.; Han, F.; Huang, Y.; Zhou, L.; Xiang, Z.; Zhao, Y.-G.; Xu, Y.; Cheng, Z.; Lu, S.; Wu, Q.; Xiang, J.-N.; Elliott, J. D.; Leung, S.; Ren, F.; Lin, X. Discovery of Biaryl Amides as Potent, Orally Bioavailable, and CNS Penetrant ROR $\gamma \mathrm{t}$ Inhibitors. ACS Med. Chem. Lett. 2015, 6, 787-792.

(17) Shirai, J.; Tomata, Y.; Kono, M.; Ochida, A.; Fukase, Y.; Sato, A.; Masada, S.; Kawamoto, T.; Yonemori, K.; Koyama, R.; Nakagawa, H.; Nakayama, M.; Uga, K.; Shibata, A.; Koga, K.; Okui, T.; Shirasaki, M.; Skene, R.; Sang, B.; Hoffman, I.; Lane, W.; Fujitani, Y.; Yamasaki, M.; Yamamoto, S. Discovery of orally efficacious ROR $\gamma \mathrm{t}$ inverse agonists, part 1: Identification of novel phenylglycinamides as lead scaffolds. Bioorg. Med. Chem. 2018, 26, 483-500.

(18) Fauber, B. P.; de Leon Boenig, G.; Burton, B.; Eidenschenk, C.; Everett, C.; Gobbi, A.; Hymowitz, S. G.; Johnson, A. R.; Liimatta, M.; Lockey, P.; Norman, M.; Ouyang, W.; Rene, O.; Wong, H. Structurebased design of substituted hexafluoroisopropanol-arylsulfonamides as modulators of RORc. Bioorg. Med. Chem. Lett. 2013, 23, 6604-6609.

(19) Solt, L. A.; Kumar, N.; He, Y.; Kamenecka, T. M.; Griffin, P. R.; Burris, T. P. Identification of a Selective ROR $\gamma$ Ligand That Suppresses TH17 Cells and Stimulates T Regulatory Cells. ACS Chem. Biol. 2012, 7, 1515-1519.

(20) Duan, J. J. W.; Lu, Z.; Jiang, B.; Stachura, S.; Weigelt, C. A.; Sack, J. S.; Khan, J.; Ruzanov, M.; Galella, M. A.; Wu, D.-R.; Yarde, M.; Shen, D.-R.; Shuster, D. J.; Borowski, V.; Xie, J. H.; Zhang, L.; Vanteru, S.; Gupta, A. K.; Mathur, A.; Zhao, Q.; Foster, W.; SalterCid, L. M.; Carter, P. H.; Dhar, T. G. M. Structure-based Discovery of Phenyl (3-Phenylpyrrolidin-3-yl)sulfones as Selective, Orally Active ROR $\gamma$ t Inverse Agonists. ACS Med. Chem. Lett. 2019, 10, 367-373.

(21) Olsson, R. I.; Xue, Y.; von Berg, S.; Aagaard, A.; McPheat, J.; Hansson, E. L.; Bernstroem, J.; Hansson, P.; Jirholt, J.; Grindebacke, H.; Leffler, A.; Chen, R.; Xiong, Y.; Ge, H.; Hansson, T. G.; Narjes, F. Benzoxazepines Achieve Potent Suppression of IL-17 Release in Human T-Helper 17 (TH17) Cells through an Induced-Fit Binding Mode to the Nuclear Receptor ROR $\gamma$. ChemMedChem 2016, 11, 207-216.

(22) Eberl, G.; Littman, D. R. The role of the nuclear hormone receptor ROR $\gamma \mathrm{t}$ in the development of lymph nodes and Peyer's patches. Immunol. Rev. 2003, 195, 81-90. 